\title{
Flipped Classroom: Its Effects on ESL Learners' Critical Thinking and Reading Comprehension Levels
}

\author{
Michael Jordan Vicencio Fulgueras \\ Philippine Normal University, Philippines \\ mj.fulgueras40@gmail.com \\ Judy Cañero Bautista \\ Philippine Normal University, Philippines \\ bautista.jc@pnu.edu.ph
}

DOI: DOI 10.36892/ijlls.v2i3.228

\begin{tabular}{ll}
\hline $\begin{array}{l}\text { Received: } \\
\text { 04/04/2020 }\end{array}$ & This experimental study investigated the effects of flipped classroom in \\
enhancing critical thinking and reading comprehension levels of 212 senior \\
Accepted: & high school ESL learners in the Philippines; half of which received the \\
conventional lecture-discussion approach to instruction and the other half & received flipped learning approach. Both the control and the experimental \\
Keywords: & groups were subjected to equal number of 15 instructional sessions. In order \\
flipped learning; & to establish the baseline data for each group in the critical thinking variable \\
reading & and the reading comprehension variable, pretests were conducted and were \\
comprehension & subsequently compared to posttest results. The t-test of two independent \\
levels; critical & samples assuming equal variances was used to determine if there was a \\
thinking levels; ESL & significant difference between the flipped classroom approach and the lecture- \\
learners & discussion approach with regard to enhancing critical thinking and reading \\
& comprehension levels. Results reveal that in both approaches, there were \\
improvements in the critical thinking levels and the reading comprehension \\
levels of the respondents. However, the results reveal that the respondents \\
who received instruction using the flipped learning approach significantly \\
outperform the respondents who received conventional instruction.
\end{tabular}

\section{INTRODUCTION}

Technology is ubiquitous in the field of education. Curriculum, educational tools, and even teaching approaches are now associated with technology as it creates structural changes which are needed by the students in achieving optimum learning. It infuses digital learning tools that build actual experiences. It encompasses $21^{\text {st }}$ century skills that create students' engagement and motivation. The uses of new teaching approaches aided by technology transform teaching styles through professional content and system that help improve the instruction and personalize learning (EDUCASE Learning Initiative, 2012; Abdelouahed, 2019). Additionally, current experiences brought about by Covid-19 or the SARS-CoV2 which limits mobility and face-to-face interaction among students and teachers conjures the idea to shift from a pure classroom-based pedagogy to a more flexible praxis using remote, online, or digital learning. 
Peck and Dorricot (1994) state that technological tools allow the teachers to make a difference, they can personalize instruction and come up with the ways that allow the students to discover the facts that they can use in acquiring and developing new knowledge. The use of technology enables the students to go beyond the target learning goal. Since technology is rampant and many can access, it can be used as platform for students to do meaningful work.

In any case, this study focused on the recently developed technology-aided teaching approach called "flipped classroom". As a relatively new teaching approach, it is not wellresearched especially in English as a learning area (Education First, 2015) in the Asian context (Thu Bui, 2018). Hamdan, McKnight, McKnight, and Arfstrom (2013) state that flipped classroom is effective in Science and Math. Additionally, the study of Love, Hodge, Grandgenette, and Swift (2013), for instance, found that in a flipped classroom approach, students significantly increased in their scores in sequential examinations on linear algebra. Similarly, in Marcey and Brint's (2011) study, 75 percent of students in a biology class had learned more in a flipped classroom approach than in the traditional approach. They posit that the flipped classroom allowed the students to experience 'cinelectures' which provided great benefits to learn the lesson.

\section{Research Problem}

Clearly, it can be observed that flipped classroom has been found effective in STEM learning areas. Nevertheless, there is dearth of data when flipped classroom is used as an approach to teach critical thinking and reading comprehension in an ESL contexts. It is for this reason that the researchers conducted this study to find out if flipped classroom can also be used effectively in teaching English as a second language with special focus on improving (1) critical thinking levels, and (2) reading comprehension levels.

\section{LITERATURE REVIEW}

The flipped classroom is a teaching approach in which the typical lecture is done outside the confines of the classroom. In this approach, prior to attending the class, students watch video lectures that the teacher had selected from online sites. This does not necessarily mean that any random video is allowed for the purpose of the flipped classroom. The video lectures should have to satisfy the necessary content that will develop the competencies of the learners in the learning area. It is important to note, however, that the lectures are not only limited to the video format. It can also be in the audio format as alternative or addition to the video which can be accessed by the students (Bergmann \& Sams, 2012). The idea of a flipped classroom promotes the concepts of active learning and student engagement. The scheduled class time is spent into workshops where students clarify the content of the lessons they have watched earlier. Subsequently, this leads to collaborative activities that serve as avenues for students to put everything they have learned into practice. Hence, teacher functions as a facilitator or coach encouraging the students to learn on their own effort (Edutopia, 2008).

Although flipped classroom appears to be a favorable approach, it does not suggest an easy procedure. It requires time for careful planning and preparation. EDUCASE Learning Initiative (2012) states that recording lectures requires a lot of effort for both teacher and students because all learning elements must be carefully integrated. In this approach, students may still complain about the loss of face-to-face lectures. They may also think that it is safe to skip a class because the idea of having the lessons available online already gives them solitary learning opportunities. Flipped classroom is a kind of teaching approach that requires trust among the students. Since the lessons are recorded and uploaded in different online sites, it would be difficult to monitor students' participation. Not having the assurance that all 
students will cooperate in a flipped classroom approach means losing the confidence of achieving the target learning goal (Edutopia, 2008).

Despite some downsides of flipped classroom, it is still believed that flipped classroom approach promotes meaningful interaction. Students under the said approach become active participants in the education process. It develops the sense of responsibility among the learners by giving them greater impetus to experiment and share what they have learned. Activities can be done by the students without much supervision and communication among students can be in a form of dynamic session. It is also a great way to achieve mastery, the idea of having the lesson accessible among the students wherever they are increases their time allotted for learning (Danker, 2015).

The discussion and activities used outside the class provide opportunities for the students to develop their critical thinking, reading comprehension, creativity and communication. Since knowledge acquisition is being done outside the class, students can discuss the lesson with their peers and can immediately raise their concern and clarification regarding the lesson (Aronson, Arfstorm \& Tam, 2013) and they can devote the instructional hours in the classroom to more engaging tasks rather than just passively receiving information from the teacher. This manifests that in a flipped classroom, students are in control of their own learning (Spino \& Trego, 2015) and that teachers are more active facilitators of learning rather than givers of information.

\section{On flipped approach in English language classrooms}

Education First (2015) enumerated several reasons why flipping an English classroom is desirable. They argue that it maximizes teacher's time. The idea of allowing the students collaborate with each other serves as great way to develop the skills that the students are struggling with. It also helps the teacher to identify who among the students most need the help. Similarly, it maximizes the learners' time. Since students already studied the lesson before attending the class, they have more time to clarify concepts and put everything they have learned into application. Consequently, students' mastery of the lesson are ensured and their concentration to tougher skills which they need to enhance are given more attention. Another reason is that it raises the engagement and motivation of every learner. Flipped classroom is an approach aided by technology in which students are more familiar, hence, more engaged (Sarpparaje, Jeyasala, Rathiga, \& Sasirekha, 2018). Since technology fuels the flipped approach, it builds the impression of fun among students, and students feel motivated to carry on with their learning.

According to Education First (2015), traditional learning forces the students to progress at an average pace which brings negative results for both slow and fast learners. Slow learners are left behind while fast learners get bored. But with flipped classroom approach, since there is more time for learning, students can build expertise in some skills in English such as 1) they can develop their vocabulary comprehension, 2) they can write complex research, 3) they can work on speaking English fluently, and 4) they can enhance their critical thinking.

Alsowat (2016) concluded that flipped approach is effective in developing students' higher order thinking skills, engagement, and satisfaction. He further revealed that since it is integrated with technology, many students can enjoy the approach without compromising quality education. He added that putting strong emphasis in autonomous learning fulfills students' needs. Incorporating technology-integrated tools towards instruction is a clear evidence that how lessons are presented plays an integral role in students' learning particularly in developing their higher order thinking skills. Additionally, Huong, Huy, and Ha (2018) concluded that flipped classroom approach enhances students critical thinking in a way that they can take full control of their own learning, students who underwent the said 
approach became more vigilant with the information they acquired. Hence, they became more rational as they expressed their own point of view. Collectively, it appears that the ideas of Alsowat (2016) and Huong, Huy, and Ha (2018) agree that the domains of higher-order thinking skills and critical thinking are shared and can therefore be interchangeable. This does not imply, however, that the two concepts are absolutely synonymous. Nevertheless, they are, in a certain perspective, related and cannot exist without the other.

\section{Flipped learning, critical thinking, and reading comprehension}

Tiruneh, Verburgh, and Elen (2012) insist that critical thinking is influenced by conditions in the instructional environment comprising the instructional variables such as teaching strategies and critical thinking approaches. Implicitly, they recognize that critical thinking can be improved if teachers design their instruction based on careful consideration of the meaningfulness and the relevance of the activities and the strategies of the teacher. Veritably, in the flipped classroom, teachers are required to carefully plan the selection of the materials that they assign to the students and they also carefully design activities that will provide avenues for the students to display what they have learned through an application activity once they meet inside the classrooms.

Similarly, Abaeian and Samadi (2016) state that flipped classroom approach provides great benefits among EFL learners' reading comprehension even if they have different proficiency levels. In their study, they advanced that students who belonged to lower intermediate level got higher scores on the test than those who belonged to upper intermediate level after the flipped approach has been utilized. The result of the study strongly argues that flipped classroom approach can be used effectively in enhancing reading comprehension level of the students.

\section{Extra considerations in the use of the flipped classroom}

Despite the emerging possibilities and promise of flipped classroom in English language classes (Arifin \& As'ad, 2019) there are still claims that must be taken into account. In point of fact, Arnsten (2013) states that flipped classroom is technology loaded and this greatly affects the willingness of students who have insufficient access to technology. She further states that it was also challenging for some students who are not technology savvy because it requires great amount of patience and willingness to fully understand how it works. In addition to this, Quizworks (2018) argue that technology issues must always be considered. Internet disconnection is one of the major issues that drives the non-utilization of flipped classroom. No internet connection means opportunity for the students to do other things, consequently decreasing their motivation to study their lesson. Hence, it could also lead to destruction of their learning attention.

Collectively, the arguments of the literature or studies cited earlier imply a potential for the use of flipped classroom as an alternative to the pure and conventional practice of hardcore lectures and face-to-face instruction. Nevertheless, it is important to consider that while flipped classroom gains a steadily increasing popularity, one has to consider the issue on equitable access of technology and the capability of students to navigate the resources when one is to utilize this kind of pedagogical practice.

\section{MATERIALS AND METHODS}

\section{Research Design}

This study used a true experimental research design that focused on unpacking the effects of flipped classroom approach in enhancing critical thinking and reading comprehension levels of senior high school ESL learners at a public urban high school in the Philippines. 
Pre-tests for critical thinking and reading comprehension, and post-tests for the same variables were administered to determine the results of the study.

\section{Participants}

The respondents of the study consisted of 212 randomly selected senior high school learners. The total number of actual respondents was acquired using the sample size determination formula with the application of proportional allocation per stratum based on the total number of senior high school students enrolled in the said high school in academic year 2018-2019. The respondents of the study were equally divided into two groups: 106 ESL learners were assigned for the experimental group and 106 ESL learners for control group. The respondents of the study came from the General Academic Strand (GAS), Accountancy and Business Management (ABM) Strand, Humanities and Social Sciences (HUMSS) Strand and Technical-Vocational (TVL) Strand offered by the school for senior high school students.

Although the respondents were randomly selected from the total population, the pool of respondents had to satisfy that their academic performance rating in the English language classes is average. Hence, the pool of respondents was composed of teacher-nominated students who fall under the average performance in the English language classes and this pool of respondents was subsequently and ultimately selected in random for their assignment in either the control group or the experimental group.

\section{Instrumentation for Critical Thinking}

The study utilized Lauren Starkey's Critical Thinking Test to determine the critical thinking levels of the ESL learners. Since the test was constructed and based on a foreign setting, some questions and options on the test were reconstructed and were subsequently validated by experts. Consequently, this test was subjected to two rounds of pilot testing and item analyses using the U-L index method so that strong validity and reliability of the test are ascertained.

The critical thinking test is composed of 30 items of multiple-choice and was scored objectively, i.e. 1 for correct answer and 0 for the wrong answer. The test is divided into areas focusing on the components of critical thinking. The areas are 1) making observations, 2) asking relevant questions and finding the resources needed, 3) challenging and examining beliefs, assumptions and opinions against facts, 4) recognizing and defining problems, 5) accessing the validity of statements and arguments, 6) making wise decisions and finding valid solutions, and 7) understanding logic and logical argument (Learning Express, 2004).

The test was constructed by Learning Express (an Elton B. Stephens Co. or EBSCO), an award-winning educational technology company which is a recognized leader in providing online workforce skills, academic, and career content for the business, education, government and library markets (EBSCO, 2015).

The questions on the test were based on the standardized tests in English like California Critical Thinking Test and Cornell Critical Thinking Test used in college admission and job application tests in the United States. The test was based on psychometric principles (Learning Express, 2004). Psychometric principles are some links in the chain of inference between statistical model and probability-based reasoning in which validity, reliability and comparability are associated (Mislevy, Wilson, Ercikan, and Chudowsky, 2001).

The critical thinking levels were based on the scores of the test, carefully checked, tallied, and analyzed. Consecutively, the test scores were interpreted using the levels stipulated in Table 1. 
Table 1. ESL Learners' Critical Thinking Levels

\begin{tabular}{|c|c|c|c|}
\hline \multicolumn{2}{|c|}{ Levels } & \multirow{2}{*}{$\begin{array}{c}\text { Test Scores/ } \\
\text { Mean scores } \\
1-11\end{array}$} & \multirow[b]{2}{*}{$\begin{array}{l}\text { Critical Thinking Skills } \\
\text { ESL learners who belong to this level were able to } \\
\text { manifest the following skills of critical thinking: } \\
\text { - identify problems and their symptoms; } \\
\text { - build awareness in situation and make good } \\
\text { inferences in context; and } \\
\text { organize thoughts and set goals in order to solve } \\
\text { problems }\end{array}$} \\
\hline Level 1 & Basic & & \\
\hline Level 2 & Good & $12-17$ & $\begin{array}{l}\text { In addition to the first level, ESL learners who belong to } \\
\text { this level demonstrated the following skills of critical } \\
\text { thinking: } \\
\text { - anticipate and recognize problems that interfere } \\
\text { their goals; and } \\
\text { - develop persuasion technique into a situation }\end{array}$ \\
\hline Level 3 & Better & $18-23$ & $\begin{array}{l}\text { In addition to the first and second level, ESL learners } \\
\text { who belong to this level possessed the following skills of } \\
\text { critical thinking: } \\
\text { - validate a study, identify invalid counter parts } \\
\text { and understand how numbers are manipulated; } \\
\text { and } \\
\text { - keep emotional response towards decision }\end{array}$ \\
\hline Level 4 & Great & $24-26$ & $\begin{array}{l}\text { In addition to the previous levels, ESL learners who } \\
\text { belong to this level illustrated the following skills of } \\
\text { critical thinking: } \\
\text { - differentiate between valid and invalid } \\
\text { deductive argument; and } \\
\text { - construct valid inductive argument }\end{array}$ \\
\hline Level 5 & Excellent & $27-30$ & $\begin{array}{l}\text { In addition to the above-mentioned components, ESL } \\
\text { learners who belong to this level exhibited the following } \\
\text { skills of critical thinking: } \\
\text { - explain and evaluate information to ensure } \\
\text { - accuracy; } \\
\text { - make fair judgment; and } \\
\text { - provide valid explanation to an argument }\end{array}$ \\
\hline
\end{tabular}

The levels of the instrument were patterned in Can Do Descriptors for the Levels of English Language Proficiency authored by the Board of Regents of the University of Wisconsin (2019) in behalf of the World-Class Instructional Design and Assessment Consortium (WIDAC). WIDAC, in their descriptors, used five levels in describing the English language proficiency of the students. Such levels are entering, beginning, developing, expanding and bridging. Each level elaborated the skills manifested by the students. Such skills were identified from the tests taken by the students in reading, writing, speaking and listening (Board of Regents of the University of Wisconsin (2019).

Similar to the descriptors created by WIDAC, the researchers used five levels to describe the critical thinking levels of the ESL learners prior and after the utilization of two different teaching approaches. Relatively, the researchers came up with their own level 
descriptors, which are 'basic', 'good', 'better', 'great', and 'excellent'. Each level specifies the critical thinking manifested by the learners after every pre-test and post-test administered.

\section{Instrumentation for Reading Comprehension}

With regard to the reading comprehension variable, the researchers of the study constructed a reading comprehension test. It was composed 40-item multiple choice and scored objectively, i.e. 1 point for each correct answer and 0 for wrong answer. Each question on the test targets specific reading comprehension skill. The selections used on the test were patterned in the subject ' $21^{\text {st }}$ Century Literature' which was one of the subjects that the ESL learners were currently taking at the time. To ensure the validity of the test, the researchers sought expert validation from a reading specialist, a curriculum developer, and a reading teacher. Subsequently, they subjected the test for initial and final pilot-testing to ensure the validity of the data-gathering instruments. The researchers consequently used the U-L index method to compute for the difficulty and discriminant indices of the items. Based on the scores and the results of the item analyses, the researchers finalized the items and they used the same taxonomy used in the critical thinking test to categorize the reading comprehension level of the learners. The taxonomy for the reading comprehension variable is presented in Table 2 .

\section{Table 2. ESL Learners Reading Comprehension Levels}

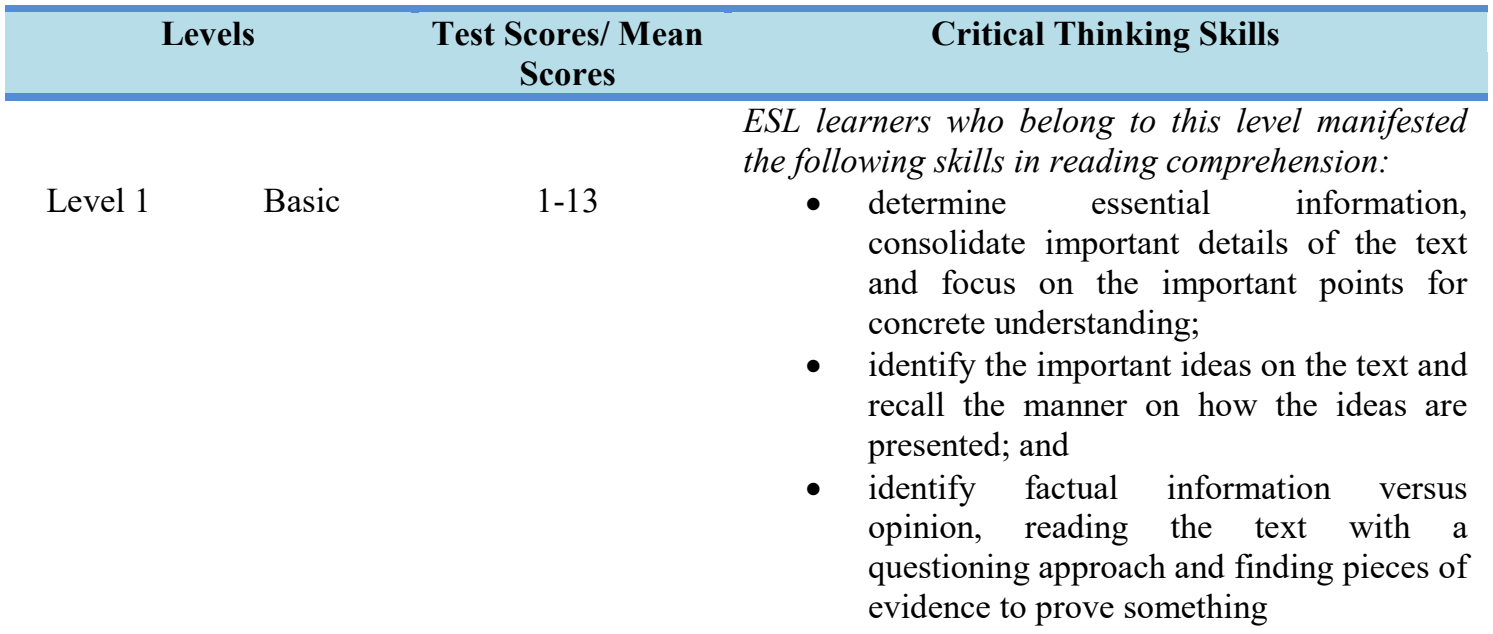

\begin{tabular}{|c|c|c|c|}
\hline Level 2 & Good & 14-19 & $\begin{array}{l}\text { In addition to the first level, ESL learners who } \\
\text { belong to this level demonstrated the following } \\
\text { skills in reading comprehension: } \\
\text { - make the implied information clearer } \\
\text { based on the pieces of evidence gathered } \\
\text { on the text; and } \\
\text { - weigh things or ideas presented on the text }\end{array}$ \\
\hline Level 3 & Better & $20-25$ & $\begin{array}{l}\text { In addition to the first and second level, ESL } \\
\text { learners who belong to this level possessed the } \\
\text { following skills in reading comprehension. } \\
\text { - associate prior knowledge and previous } \\
\text { experiences to understand and remember } \\
\text { what was read }\end{array}$ \\
\hline & & & $\begin{array}{l}\text { In addition to the previous levels, ESL learners who } \\
\text { belong to this level illustrated the following skills } \\
\text { reading comprehension: }\end{array}$ \\
\hline
\end{tabular}




\begin{tabular}{|c|c|c|c|}
\hline Level 4 & Great & $26-33$ & $\begin{array}{l}\text { - determine author's message and locate } \\
\text { important details that provide framework } \\
\text { to remember the content of the text; and } \\
\text { draw conclusions based on the text and fill } \\
\text { in information that wasn't clearly } \\
\text { presented }\end{array}$ \\
\hline Level 5 & Excellent & $34-40$ & $\begin{array}{l}\text { In addition to the above-mentioned components, } \\
\text { ESL learners who belong to this level exhibited the } \\
\text { following skills of reading comprehension: } \\
\text { - come up with logical ideas by generating, } \\
\text { investigating, and answering questions to } \\
\text { satisfy curiosity about the text; and } \\
\text { - } \\
\text { solve a problem presented in the text. Use } \\
\text { understanding, critical thinking, and actual } \\
\text { experiences to come up with a solution to } \\
\text { a problem }\end{array}$ \\
\hline
\end{tabular}

\section{Data-Gathering Procedures and Statistical Analysis}

The experimental group and control group have undergone flipped classroom approach and lecture-discussion approach respectively. The approaches were administered by another language teacher. To ensure the language teacher is guided with the difference of flipped classroom approach and lecture-discussion approach, the researchers conducted a training so that the teacher may execute both conventional and intervention approaches respective of the control group and experimental group. The lessons for critical thinking were based on Lauren Starkey's book "Critical Thinking Skills Success in 20 Minutes" and other instructional materials that focused on the ways on how to enhance student's critical thinking skills in English. Meanwhile, the lessons for reading comprehension were based on various reading comprehension references that target the skills of reading comprehension.

The reading comprehension selections were patterned on the 21st Century Literature, a subject for senior high school students offered by the Department of Education in the Philippines. The literary texts were composed of stories, poems, and essays written by some Filipino writers for the purpose of identifying representative texts and authors from the regions and developing appreciation. Hence, the texts used are composed of narrative, literary, and expository genres.

The researchers acquired permission from the Schools Division Superintendent of Quezon City and the principal of the senior high school to conduct the study. Prior to the utilization of the approaches, the nature and context of the study and the process of data gathering were discussed among the respondents who need to be protected for ethical considerations. Since, majority of the respondents are minors, parental consent forms were distributed to their parents to seek approval regarding the participation of their children in the study. Participant safety and confidentiality were strictly enforced in the whole duration of the investigation.

In the 15 sessions, both approaches were utilized. The lessons in flipped classroom approach and lecture-discussion approach were the same in their focus on enhancing critical thinking and reading comprehension levels. The difference only lies in terms of delivery and presentation because lessons in the flipped classroom were presented through videos, audio and text pre-uploaded in a selected online repository like Facebook (Edutopia, 2008) while the lessons in lecture-discussion approach were presented using PowerPoint presentations and other visual materials that were given during actual instructional hours.

Both groups have taken their pre-test for the baseline and post-test for the data on effects in order to gauge their critical thinking and reading comprehension levels. The results 
of the post-tests were analyzed and compared to the baseline data in order to determine if there is a significant difference between flipped classroom approach and lecture-discussion approach in enhancing critical thinking and reading comprehension levels of the ESL learners.

After gathering all the needed data, the test scores obtained by the respondents in pretest and posttest were computed by a statistician using t-test of two independent samples assuming equal variances to determine if there is a significant difference between the flipped classroom approach and the lecture-discussion approach in enhancing the critical thinking and reading comprehension levels of the ESL learners.

\section{RESULTS AND DISCUSSION}

\section{Baseline Data and Discussion}

Table 3 presents the ESL learners' critical thinking and reading comprehension levels prior to the utilization of the flipped classroom approach and the lecture-discussion approach.

Table 3. Baseline Data of the Control and Experimental Groups for Critical Thinking and Reading Comprehension based on Mean Scores $(N=212)$

\begin{tabular}{|c|c|c|c|c}
\hline \multicolumn{1}{c}{ Dependent Variables } & Groups & Mean Scores & Level & Level Descriptors \\
\cline { 2 - 5 } Critical Thinking & Control & 10.8679 & 1 & Basic \\
\cline { 2 - 5 } & Experimental & 10.1981 & 1 & Basic \\
\hline \multirow{2}{*}{ Reading Comprehension } & Control & 17.7736 & 2 & Good \\
\cline { 2 - 5 } & Experimental & 17.5283 & 2 & Good \\
\hline
\end{tabular}

Based on the results of the critical thinking pre-test, data reveal that the control group acquired a mean score of 10.8679. On the other hand, the experimental group obtained a mean score of 10.1981. The difference between the mean scores of the two groups is .67 in favour of the control group. This implies that ESL learners in the control group scored relatively higher than the experimental group. Nevertheless, both groups manifested the same level of critical thinking based on the mean scores of the pre-test, i.e. 'basic level'. Hence, it may be safe to assume that integration of teaching approaches may be considered to develop the critical thinking level of the respondents (Abrami, Bernard, Borokhovski, Wade, Surkes, Tamim, and Zhang, 2008).

With regard to the reading comprehension pre-test, data show that the control group acquired a mean score of 17.7736 while the experimental group obtained a mean score of 17.5283. The difference of the mean scores of the two groups is .25 in favor of the control group. This implies that ESL learners in the control group scored relatively higher than the experimental group. Nonetheless, both control and experimental group manifested the same level of reading comprehension skills based on the pre-test results, i.e. 'good level' which indicates that both were comparable prior to the utilization of flipped classroom approach and lecture-discussion approach. Thus, it may be a good opportunity for teaching approaches to come into play to enhance reading comprehension levels (Stearns, 2012).

\section{Post-Intervention Data and Discussion}

Table 4 presents ESL learners' critical thinking and reading comprehension levels after the utilization of the flipped classroom approach and the lecture-discussion approach. 
Table 4. Post-test Data of the Control and Experimental Groups for Critical Thinking and Reading Comprehension based on Mean Scores ( $N=212)$

\begin{tabular}{c|c|c|c|c}
\hline Dependent Variables & Groups & Mean Scores & Level & Level Descriptors \\
\hline \multirow{2}{*}{ Critical Thinking } & Control & 14.5472 & 2 & Good \\
\cline { 2 - 5 } & Experimental & 18.8679 & 3 & Better \\
\hline \multirow{2}{*}{ Reading Comprehension } & Control & 21.0472 & 3 & Better \\
\cline { 2 - 5 } & Experimental & 26.7830 & 4 & Great \\
\hline
\end{tabular}

Based on the results of the critical thinking post-test, the control group acquired a mean score of 14.5472 which fell under the 'good level'. On the other hand, the experimental group obtained a mean score of 18.8679 which made them reach the 'better level'. Both groups improved their critical thinking levels after the implementation of the flipped classroom and the lecture-discussion approach. The control group which is initially in the 'basic level' reached the 'good level'. On the other hand, the experimental group which is, at first, in the 'basic level' ended in the 'better level'.

As regards the results of the reading comprehension posttest, it appears that the control group acquired a mean score of 21.0472 whereas the experimental group obtained a mean score of 26.7830. Both groups improved in their reading comprehension level after the utilization of the flipped classroom approach and the lecture-discussion approach. Control group which was in the 'good level' of reading comprehension now reached the 'better level' while the experimental group which was also in the 'good level' in the pre-test phase now ended in the 'great level'. It appears that the deliberate use of a teaching approach plays a vital role in enhancing reading comprehension levels of the learners (Spino \& Trego, 2015).

\section{Intervention Differences}

Table 5 presents the difference between the flipped classroom approach and the lecture-discussion approach in enhancing the critical thinking and the reading comprehension levels of the ESL learners.

Table 5. Comparison of the Control Group and Experimental Group Mean Scores in Critical Thinking and Reading Comprehension Levels $(N=212)$

\begin{tabular}{|c|c|c|c|c|c|}
\hline $\begin{array}{l}\text { Dependent } \\
\text { Variables }\end{array}$ & Groups & Mean Scores & $\begin{array}{l}\text { Standard } \\
\text { Deviation }\end{array}$ & t-value & $\begin{array}{l}\text { p-value (Two- } \\
\text { tailed) }\end{array}$ \\
\hline \multirow[t]{2}{*}{ Critical Thinking } & Control & 14.5472 & 4.88951 & \multirow[t]{2}{*}{31.226} & \multirow[t]{2}{*}{0.000} \\
\hline & Experimental & 18.8679 & 5.42845 & & \\
\hline \multirow{2}{*}{$\begin{array}{c}\text { Reading } \\
\text { Comprehension }\end{array}$} & Control & 21.0472 & 7.46979 & \multirow[t]{2}{*}{-35.019} & \multirow[t]{2}{*}{0.000} \\
\hline & Experimental & 26.7830 & 8.57239 & & \\
\hline
\end{tabular}

Based on the mean scores of the two groups in critical thinking post-test, data reveal that the control group who received the lecture-discussion approach acquired a mean score of 14.5472 with a standard deviation of 4.89 while the experimental group who underwent the flipped classroom approach obtained a mean score of 18.8679 with a standard deviation of 5.43. Using the t-test of two-sample (independent samples) with equal variances assumed, there is a significant difference between the mean scores of the two groups. The t-value is 31.226 with $p=0.000$. The difference of the mean scores of the two groups' post-test results is 4.32 in favor of the experimental group. This implies that flipped classroom as an instructional intervention is more effective in developing students' higher order thinking skills compared with the lecture-discussion approach (Alsowat, 2016). Moreover, it can be 
affirmed that critical thinking is greatly influenced by the condition of learning environment; that students can develop their critical thinking depending on the teaching intervention suited to them like flipped classroom (Tiruneh, Verburgh, \& Elen 2012). The findings also agreed with Huong, Huy, and Ha (2018) who revealed that flipped classroom approach enhances students' critical thinking in a way that they can take full control of their own learning; they become more vigilant with the information they acquired. Hence, they become more rational as they express their own point of view.

With regard to the mean scores of the two groups in reading comprehension posttest, it can be noted that the control group who were instructed using the lecture-discussion approach acquired a mean score of 21.0472 with standard deviation of 7.47 whereas the experimental group who were facilitated under the flipped classroom approach obtained a mean score of 26.7830 with standard deviation of 8.57 . Using the t-test of two-sample (independent samples) with equal variances assumed, there is a significant difference between the mean scores of the two groups. The $t$-value is -35.019 with $p=0.000$. The mean score difference of the two groups' post-test results is 5.74 in favor of those students who were taught under flipped classroom approach. This signifies that associating various technological tools like flipped classroom develop students reading comprehension skills than the lecture-discussion approach (Stearns, 2012). Furthermore, it can be stated that flipped classroom provides students enough time for learning which help them master the skills they need in reading comprehension. The idea of having the lessons customized can be considered as an effective way to cover all aspects of reading comprehension that students must possess (Abaeian \& Samadi, 2016). More so, the students in a flipped classroom approach become more active learners; they acquire and develop their own understanding of the reading lessons; they make meaning out of the text. Thus, they build connection based on different perspectives (Arkansas State University, 2017).

\section{CONCLUSION}

The flipped classroom approach enhances students' critical thinking and reading comprehension levels. This is consistent with the claims forwarded by Alsowat (2016), Huong, Huy, and Ha (2018), and Abaeian and Samadi (2016). Therefore, providing students the opportunity to learn at their own pace, allowing them to collaborate with their classmates, and letting them raise concerns and clarifications in a timely manner can be considered as effective ways to develop their critical thinking and reading comprehension. Even though the findings manifested earlier clearly show that students benefit in conventional lecturediscussion, the flipped classroom approach provides better opportunities for students to maximize their learning in the ESL classroom especially with regard to the development of their critical thinking and reading comprehension levels.

Further investigations are needed with regard to the current study. It is important to note that the length of the intervention for the experimental group and the length of conventional instruction used in the control group may still be administered using a longer time period in order to establish if there is a considerable disparity between the effects of the intervention in contrast to the conventional instruction because, apparently, in this study, the flipped classroom better enhances reading comprehension levels than the critical thinking levels. Had the intervention and the conventional instruction been administered twice or thrice the number of sessions mentioned earlier, results may have distinguished the more effective pedagogical practice.

Additionally, current results raise an issue as regards the existence or the non-existence of interdependence between reading comprehension and critical thinking. The researchers, therefore, encourage scholars to explore and describe, if there is any, the interdependence of 
critical thinking and reading comprehension levels in the context of English language teaching and learning. This recommendation for future research is needed in order to make a strong link between reading comprehension and critical thinking. Furthermore, it will help establish a theory on either the causality or the relationship of the two variables.

\section{REFERENCES}

Abaeian, H., \& Samadi, L. (2016). The effect of flipped classroom on Iranian EFL learners' L2 reading comprehension: Focusing on different proficiency. Journal of Applied Linguistics and Language Research, 3(6), 295-304.

Abdelouahed, L. (2019). The Implementation of Collaborative Learning via Virtual Communities in Moroccan Higher Education: A focus on EFL Undergraduate Students. International Journal of Language and Literary Studies, 1 (2), 60-73.

Abrami, P. C., Bernard, R. M., Borokhovski, E., Wade, A., Surkes, M. A., Tamim, R., \& Zhang, Dai. (2008). Instructional interventions affecting critical thinking skills and dispositions: A stage 1 meta-analysis. Review of Educational Research, 78(4), $1102-1134$.

Alsowat, H. (2016). An EFL flipped classroom teaching model: Effects on English language higher-order thinking skills, student engagement and satisfaction. Journal of Education and Practice 7(9), 108-118.

Arakansas State University. (2017). Can a flipped classroom improve reading?. Retrieved from https://degree.astate.edu/articles/k-12-education/can-a-flippedclassroom-improve-reading.aspx

Arifin, M.A., \& As'ad, M.S. (2019). Student Engagement, Collaborative Learning, and Flipped Classroom as Basis for a Blended Language Learning Environment. The Asian EFL Journal, 24 (4), pp. 38-44.

Aronson, M., Arfstrom, K., \& Tam, K. (2013). Flipped learning in higher education. Retrieved from Retrieved from https://flippedlearning.org/wpcontent/uploads/2016/07/HigherEdWhitePaper-FINAL.pdf

Arnsten, T. (2013). The flipped classroom. Retrieved from http://blog.tesol.org/theflipped-classroom/

Bergmann, J., \& Sams, A. (2012). Flip your classroom: Reach every student, in every class, every day. Oregon: Courtney Burkholder.

Danker, B. (2015). Using flipped classroom approach to explore deep learning in large classrooms. IAFOR Journal of Education, 3 (1).

EBSCO (2015). Learning express helps students prepare for the new SAT test. News Center: Press Release.

Education First (2015). Flipped English learning. How businesses are getting 
strategic about English and turning old-school learning on its head.

http://www.efitalia.it/_ /media/centralefcom/corporate/2015/Resources/pdf/Flipped

Learning

EDUCASE Learning Initiative, (2012). 7 things you should know about flipped

classrooms. Retrieved from https://library.educause.edu/resources /2012/2/7-things-

you-should-know-about-flipped-classrooms

Edutopia, (2008). Why integrate technology into curriculum?: The reasons are many. Retrived from

https://laulima.hawaii.edu/access/content/user/jaydene/ED100/ED100.Article.Why\%2 0Integrate $\% 20$ Technology $\% 20$ into $\% 20$ the $\% 20$ Curriculum.pdf

Hamdan, N., Mcknight, K., Mcknight, P., \& Arfstrom, K. (2013). A review of flipped learning. Flipped Learning Network. Retrieved from https://flippedlearning.org/wpcontent/uploads/2016/07/LitReview_FlippedLearning.p $\underline{\mathrm{df}}$

Ha Thi Lan Huong, Nguyen Hoang Doan Huy and Nguyen Ngoc Ha. The Flipped Classroom: Using Thematic Teaching to Develop Critical Thinking for High School Students. American Journal of Educational Research. 2018; 6(6):828-835. doi: 10.12691/education-6-6-36

Learning Express (2004) Critical thinking skills success. Leaning Express, LLS: N.Y.

Love, B., Hodge, A., Grandgenenett, N., \& Swift, A. (2013). Student learning and perceptions in a flipped linear Algebra course. International Journal of Mathematical Education in Science and Technology. Retrieved October 9, 2017 from http://www.tandfonline.com/doi/abs/10.1080/ 0020739X .2013.822582

Marcey, D. J., \& Brint, M. E. (2011). Transforming an undergraduate introductory biology course through cinematic lectures and inverted classes: A preliminary assessment of the Clic model of the flipped classroom. Retrieved from https://nabt.org/files/galleries/Marcey_Brint.pdf

Mislevy R.J., Wilson M.R., Ercikan K., Chudowsky N. (2003) Psychometric Principles in Student Assessment. In: Kellaghan T., Stufflebeam D.L. (eds) International Handbook of Educational Evaluation. Kluwer International Handbooks of Education, vol 9. Springer, Dordrecht

Peck, K. and Doricot, K., (1994). Realizing the promise of technology: Why use technology. Retrieved from http://www.ascd.org/publications/educationalleadership/apr94/vo151/num07/Why-Use-Technologye.aspx

Quizworks (2020). Flipped classroom advantages and disadvantages. Retrieved from https://www.easy-lms.com/knowledge-center/about-flipped-classroom/flippedclassroom-advantages-and-disadvantages/item 10610 
Sarpparaje, M., Jeyasala, V.R., Rathiga, K., \& Sasirekha, K. (2018). Flipped Classroom Approach to make the Best Untilization of ESL Classes at Mepco Schlenk Engineering College - A Try Out. The Asian ESP Journal, 14 (7.2), pp. 209-228.

Spino, L., and Trego, D. (2015). Strategies for flipping communicative language classes. Retrieved from http://clear.web.cal.msu.edu/wpcontent/uploads/sites/22/2018/10/CLEAR_Newsletter_Spring_15 FINAL.pdf

Stearns, S. C. (2012). Integration of technology into the classroom: Effects on reading comprehension. Southern Illinois UniversityCarbondale: OpenSIUC. Retrieved from https://opensiuc.lib.siu.edu/cgi/viewcontent.cgi?referer=https://www.google.com/\&htt psredir $=1 \&$ article $=1314 \&$ context $=$ gs_rp

Thu Bui, T. (2018). Flipped learning: A Possible Model in the Vietnamese EFL Tertiary Context. The Asian EFL Journal, 20 (8), 69-75.

Tiruneh D., Verburgh, A., and Elen, J. (2012). Effectiveness of critical thinking instruction in higher education: A systematic review of intervention studies. Canadian Center of Science and Education. Higher Education Studies, 4, (1). Retrieved from www.ccsenet.org/journal/index.php/hes/article/view/32095

Board of Regents of the University of Wisconsin (2019). Access for ELLs interpretive guide for score reports: Grades K-12, Spring 2020. Retrieved from https://wida.wisc.edu/sites/default/files/resource/Interpretive-Guide.pdf

\section{$\underline{\text { AUTHORS' BIOS }}$}

Michael Jordan Vicencio Fulgueras, M.A. is a fulltime English language teacher at a public secondary school in the Philippines and he is a recent graduate of Master of Arts in English Language Teaching at the Philippine Normal University, Manila. His research interests are flipped approach to language teaching, technology-based language teaching methodologies, second language acquisition, and discourse analysis.

Judy C. Bautista, Ph.D. is an associate professor of reading and literacy education at the College of Graduate Studies and Teacher Education Research of the Philippine Normal University, Manila. His research interests include second language acquisition studies, psychology and pedagogy of reading, visual literacy, visual social semiotics, community literacy, language and literacy research methodologies, and verbal protocol analysis. 